\title{
Parks and Reserves in Congo Brazzaville
}

\author{
C. A. Spinage
}

Little is known about the wildlife of the People's Republic of the Congo Congo Brazzaville. Because the land was once entirely forest almost the only large mammals are those of forest habitat. The author, who went on a two-week mission for FAO/UNDP in 1978, describes the few protected areas, which include one national park, and also the area proposed for a new national park where manatees are thought to be 'not uncommon'.

The People's Republic of the Congo, or Congo Brazzaville, formerly Moyen-Congo, is one of those former French possessions in equatorial Africa about which English-speaking people know little. This extends to its wildlife protection, published references to which are often woefully inaccurate.

The country's large mammal fauna is very impoverished. Formerly, tropical rain forest probably covered the entire area; the open grasslands are the result of burning, and it is striking how these grasslands border the roads and logging tracks. As a result there is no true plains fauna; with the exception of lion, hunting dog and reedbuck, the large mammals consist of the limited species associations relevant to a forest habitat. Malbrant and Maclatchy list the following large mammals for the region: ${ }^{1}$

Gorilla Gorilla g. gorilla, chimpanzee Pan troglodytes, mandrill Papio mandrillus, forest elephant Loxodonta africana cyclotis, manatee Trichechus senegalensis, bushpig Potomachoerus porcus, yellow baboon Papio cynocephalus, 10 species of monkey, hunting $\operatorname{dog}$ Lycaon pictus, side-striped jackal Canis adustus, spotted hyaena Crocuta crocuta, leopard Panthera pardus, caracal $F$ elis caracal, serval $F$. serval, golden cat $F$. aurata, giant forest hog Hylochoerus meinertzhageni, hippopotamus Hippopotamus amphibius, water chevrotain Hyemoschus aquaticus, bushbuck Tragelaphus scriptus, sitatunga $T$. spekei, bongo Boocerus euryceros, reedbuck Redunca arundinum, defassa waterbuck Kobus defassa, forest buffalo Syncerus caffer nanus, 6 duiker species Cephalophus/Sylvicapra spp.

Of these the most commonly seen are waterbuck and buffalo. A 1948 government map of the Mont Fouari area, in the custom of ancient cartographers, fills up the blank spaces with a list of animals to be found in the adjoining Ndendé hunting reserve in Gabon: 'elephants, buffalo, sitatunga, waterbuck, reedbuck, yellow-backed duiker, leopards'. It is clear that these areas have never been rich in species.

Wildlife protection and hunting are under the Ministry of Rural Economy and are administered as in other former French possessions by the Départément des Eaux et Forêts. Approximately 51 persons are employed in the Hunting and Wild Life Protection Service, 15 of whom have been trained at the Garous School for the Training of Wildlife Specialists. The annual salary budget amounts to some $£ 25,000$ and in 1977 the Department received no money other than for salaries. During 1978-79 some $£ 46,000$ was budgeted for development, but the money did not materialise. It is the familiar problem, stemming from colonial times in both English- and French-speaking countries, of inadequately staffed and inadequately budgeted departments to which the Government attaches little importance. 


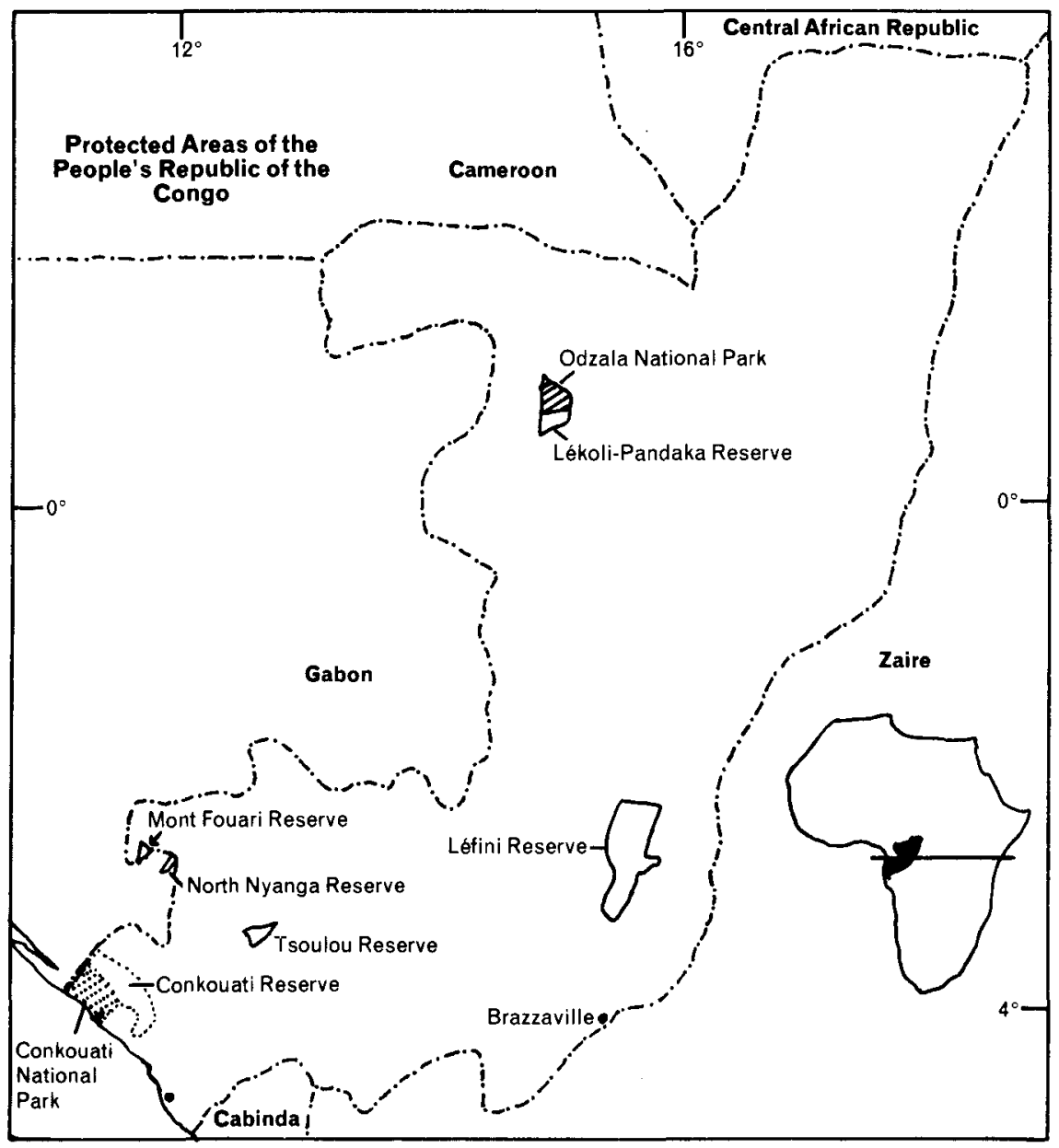

Protected areas are of four kinds:

1 Domaine de Chasse: an area where hunting is allowed only with a big game hunting permit (permis de grande chasse) which limits the number of animals that can be taken:

2 Réserve de Chasse: a domaine de chasse that has been closed to hunting for a limited period;

3 Réserve de Faune: hunting is totally prohibited, but other traditional rights of usage are allowed. Other terms such as Réserve Totale de la Faune and Réserve Partielle de la Faune appear to be loose connotations of the same term;

4 Parc National: where all human rights of usage are excluded.

At present these protected areas total some $9000 \mathrm{sq} \mathrm{km}$, representing less than 2.5 per cent of the land surface. Only one area has the status of a national park; the remaining five are faunal reserves, of which two do not appear to have been 
officially gazetted. A further national park and a faunal reserve are proposed. The protected areas are very thinly populated and there is little hunting. The biggest threat is commercial poaching for meat for the towns.

\section{Odzala National Park}

The only national park is in the north-west, some $780 \mathrm{~km}$ from Brazzaville. Although declared to be 110,000 hectares in area, it appears from the 1:200,000 map to be of the order of 126,000ha. Created in 1935 as a Strict Natural Reserve, it was gazetted as a national park in 1940 (Arrêté no 2243 of 27.7.40). This law provided for a more precise definition of the boundaries to be established, but this has never been done.

The park is virtually unknown, but appears to consist entirely of tropical rain forest. The sandy roads make it almost inaccessible and no studies have ever been conducted there. It is said to have a good population of lowland gorilla, which seems to be relatively common in the country, and presumably has also the typical forest fauna of the region. It is said to be visited only by pygmies. The annual rainfall is between 1600 and $1800 \mathrm{~mm}$.

\section{The Lékoli-Pandaka Faunal Reserve}

Created in 1955, this reserve adjoins the southern boundary of the Odzala National Park, and contains an area of Andropogon open savanna country almost certainly the result of fire and cultivation. Its size is given as 50,000ha, but the true area appears to be some $68,200 \mathrm{ha}$. Lions are said to be relatively common in the savanna part, and buffalo are numerous; otherwise the fauna is that of the tropical rain forest.

\section{Léfini Faunal Reserve}

Originally a hunting reserve, this is now termed a faunal reserve but does not appear to have been officially gazetted. It comprises the largest protected area in the country, some 630,000 ha (calculated from the map) although the given area is 650,000 ha. It consists mainly of open fire-induced Trachypogon and Hyparrhenia grassland, dissected by two river gorges in the north and the Léfini river in the middle; the southern part is broken, hilly country. For the most part it falls within the 1600 and $1800 \mathrm{~mm}$ isohyets. The commonest species are probably waterbuck and buffalo, but most of the game is said to have been hunted out.

\section{Tsoulou Faunal Reserve}

Originally a hunting area like the Léfini, and also not officially gazetted, this is a small reserve given as $30,000 \mathrm{ha}$. The date of its formation was not ascertained, but is fairly recent. The vegetation comprises forest remnants and Trachypogon grasslands. It is said to harbour gorilla and buffalo, among other species. The rainfall is between 1200 and $1400 \mathrm{~mm}$.

\section{Mont Fouari Faunal Reserve}

Another small reserve, originally lying partly in Gabon and now totalling only 15,600 ha in the Congo, this is the only one with motorable tracks; it also has three well-constructed bungalows, although these have fallen into disrepair. In the 1960 s, when it was popular with local expatriates, this reserve had good numbers of buffalo, but these were largely destroyed by the military in 1970 on orders from the government; since then the area has been neglected. It still has 
four rangers, who say that local people poach freely. The area is relatively attractive, with gently undulating grasslands framed by the low, forested ridge of Mont Fouari rising steeply in the background. The grasslands, which are maintained by the fierce annual fires set usually in September, consist of typically fire-resistant species such as Trachypogon, Cymbopogon giganteus, Hyparrhenia species and Eragrostis superba. It is in one of the driest parts of the country with an annual rainfall averaging $1200 \mathrm{~mm}$. Some buffalo survive, but waterbuck is the commonest species. Bushpigs and bushbuck are the only others likely to be seen occasionally; even hyaena are absent. Some elephants visit the area each year, but apparently return to the Gabon side as soon as they are shot at.

\section{North Nyanga Faunal Reserve}

Separated from the Mont Fouari reserve by a hunting sector, this very small reserve comprises a narrow strip some three kilometres wide between that hunting sector and another, along the west bank of the Nyanga river. Although given as $18,000 \mathrm{ha}$, I calculate the area to be no more than $7700 \mathrm{ha}$. It is in every respect similar to the Mont Fouari reserve, but its purpose is apparently to protect the hippopotamus in the Nyanga river.

\section{A New National Park?}

Proposals are in hand to create a national park and a faunal reserve centering on a group of lagoons near the coast: Lakes Tchibenda, Tchivoka and Tchimba, known loosely as Conkouati. This park would stretch from the coast, with its deserted white sand beaches bordering the Atlantic, inland to the Kouboula Mountains, a range of steep-sided, densely forested hills. The lakes decrease in salinity as one passes inland, so that Tchibenda, the farthest inland, is probably entirely fresh; while the Conkouati lagoon near to the coast is salt, with bordering mangroves and typical marine life. For the most part the area is covered with tropical forest which has been well exploited, except in the Kouboula Mountains. Near to the coast and the Conkouati lagoon there is some open, fire-derived grassland. The greatest conservation benefit of this national park would be the protection of the manatee, which apparently is not uncommon here. Elephant, buffalo, waterbuck, gorilla and chimpanzee all occur, but are seldom seen. The proposals envisage a national park between 27,700 and 87,700 ha (depending on which proposal is accepted); and a faunal reserve of possibly 127,000 ha.

As in many other countries, protection in Congo Brazzaville is largely paper protection. Guards are assigned to all the areas but are generally in inadequate numbers, without transport or proper supervision, and poaching is widespread in all accessible areas. The government has signified an interest in correcting the situation, primarily with a view to reaping some material benefit in the way of tourism. At present, however, the financial difficulties of the country render any significant change improbable, unless considerable outside interest is forthcoming.

\section{Reference}

1 MALBRANT, R. and MACLATCHY, A. 1949. Faune de l'Equateur Africain Français, Encyclop. Biol. 36. Paris.

Dr C.A. Spinage, c/o UNDP, B.P. 872, Bangui, Central African Republic. 